\title{
Moisture Retention in the Organic Soils of Caño Tiburones ${ }^{1}$
}

\author{
Raúl Pérez-Escolar, J. Juárez, Jr., J. A. Bonnet, and M. A. Lugo López ${ }^{2}$
}

\section{INTRODUCTION}

Most soils of Puerto Rico are of a mineral origin with only some 25,000 acres of organic soils (6). These organic soils are mainly scattered throughout the coastal lowlands. The largest single body occurs in the northern part of the island in the vicinity of Arecibo and Barceloneta. The area is known as Caño Tiburones and comprises some 5,600 acres of land. This area has been largely reclaimed through extensive drainage and was planted for a time to sugarcane. However, yields are rather low and many management problems have arisen since the swamp was drained including settling, salinity, high acidity, and others.

Formal research on these problem soils has been rather limited. Knowledge of the physical behavior of the soils is scarce or nonexistent. About the only data available in the literature was reported by Lugo-tópez and Bonnet (6) in 1951 from a generalized study of the organic soils of Puerto Rico. These data were limited to bulk density and porosity measurements.

The reclamation of the organic soils of Caño Tiburones for agricultural purposes has been an expensive proposition. However, on an island with such limited land resources as Puerto Rico, such an endeavor must be evaluated not only in terms of expenditures but also in terms of added permanent assets to the country. If properly managed, organic soils can be highly productive as has been proved in the Fens of England, the "veens" of Holland, the Everglades of Florida and the muck land of Michigan, Minnesota, New York, and other areas $(1,3,4)$. If improperly managed, production can be low and soil losses through oxidation can deteriorate the soil at a quick pace. The investments already made and the potential agricultural value of the Caño Tiburones soils, which is evident, call for the development of management practices and techniques that can assure a permanent agriculture on these lands.

In an attempt to increase the knowledge of organic soils and to better understand the behavior of the soils of the Caño Tiburones area, exploratory tests were recently made to determine the moisture retention and release status of these soils. This paper reports data on bulk density,

1 Manuscript submitted to Editorial Board April 9, 1973.

Soil Scientist, Agricultural Experiment Station, Mayagüez Campus, University of Puerto Rico, Rio Piedras and Mayaguiez, P.R. Dr. Bonnet, former Head of the Soils Department, is now retired. 
moisture retention at $1 / 2$ and 10 atmospheres and "available water" for the three organic soils recognized in the Caño Tiburones area.

\section{BRIEF DESCRIPTION OF THE SOILS}

Roberts (7) recently conducted a soils survey of the Caño Tiburones area as part of a more comprehensive study by Bonnet (2) ${ }^{3}$ on the characterization of the soils and the identification of the problems affecting their use. Roberts recognized the Tiburones muck as the most extensive soil of the area. He also differentiated various phases, namely, calcareous, muck over clay, and muck over sand. The typical soil has a black, strong, fine-granular, water-stable, acid-muck surface about 12 to 14 inches thick. This layer rests over an acid, mottled grey and yellowish-brown silty clay loam or silt which is platy to massive and channeled vertically by old root holes. Sulfate-sulfur occurs in splotches, streaks and along root holes and structural units. This layer is underlain by a 15- to 20-inch thick, very dark brown, very acid, fibrous muck which grades into a more fibrous, neutral to acid, peat layer at a depth of 30 to 40 inches. This is underlain by old lagoon deposits at depths ranging from 6 to 22 feet.

Factor muck has an upper 15- to 18-inch, black, strongly granular, alkaline to strongly calcareous muck layer which is very hard when dry, but friable, slightly sticky and slightly plastic when wet. The subsoil is 20 to 30 inches thick and consists of white, highly calcareous marl. It is massive and hard when dry and very sticky and plastic when wet. This marl is underlain by sandy fibrous peat with $\mathrm{pH}$ usually around 6 .

Factor marly muck differs from Factor muck in that it has a surface layer consisting of a very high percentage of calcium carbonate or marl from mollusk shells. In most places the surface is white. This layer dries out soon after a rain. The surface material is underlain at a depth of 20 inches by a 15- to 20 -inch thick black calcareous muck similar to the surface layer of Factor muck. This is underlain by stratified layers or marl, muck and peat.

\section{PROCEDURE}

Undisturbed soil cores were taken by using a 3-inch-in-diameter by 3-inch-in-length metal sampler of the Uhland type. The cores were dried in an oven at $110^{\circ} \mathrm{C}$ and the bulk density was calculated by dividing the net dry weight of the soil by its original volume. From these data the weight of an acre-furrow slice was calculated. Disturbed soil samples were also taken for moisture content determinations. The moisture retained at $1 / 2$ and 10 atmospheres was determined by submitting saturated soil samples

study undertaken by Dr. J. A. Bonnet, as consultant to the Land Authority of Puerto Rico. 
to the respective pressures in special plates until equilibrium was reached. In this paper information is provided on the difference between moisture content at 1/2 atmosphere of pressure and that remaining in the soil pores when subjected to 10 atmospheres of pressure. Under laboratory conditions it was impossible, at the time this work was conducted, to build up pressure plate tension to the accepted 15 atmospheres so the lower limit considered here is only the 10 -atmosphere tension moisture content.

\section{RESULTS AND DISCUSSION}

Data on bulk density, weight of acre-furrow slice, moisture retained at 1/2 and 10 atmospheres and "available water" (the difference between such water retentions) are presented in table 1. In general, bulk density

TABLE 1.-Bulk densily, weight of acre-furrow slice, moisture relained at $1 / 2$ and 10 atmospheres of pressure and "available waler" 1 of organic soils from Caño Tiburones

\begin{tabular}{|c|c|c|c|c|c|c|}
\hline \multirow[t]{2}{*}{ Soil } & \multirow{2}{*}{$\begin{array}{c}\text { Sampling } \\
\text { depth }\end{array}$} & \multirow{2}{*}{$\begin{array}{c}\text { Bulk } \\
\text { density }\end{array}$} & \multirow{2}{*}{$\begin{array}{l}\text { Weight of acre- } \\
\text { furrow slice }\end{array}$} & \multicolumn{2}{|c|}{$\begin{array}{l}\text { Moisture retained at } \\
\text { indicated atmospheres } \\
\text { of pressure }\end{array}$} & \multirow{2}{*}{$\begin{array}{c}\text { "Avail- } \\
\text { able } \\
\text { water" }\end{array}$} \\
\hline & & & & $1 / 2$ & 10 & \\
\hline & Inclies & $G m / c c$ & Lbs & $\begin{array}{c}\text { Percent by } \\
\text { weight }\end{array}$ & $\begin{array}{c}\text { Percent by } \\
\text { woeight }\end{array}$ & $\begin{array}{c}\text { Percent by } \\
\text { weight }\end{array}$ \\
\hline \multirow[t]{2}{*}{ Tiburones muck } & $0-3$ & 0.56 & 761,080 & 98.3 & 84.4 & 13.9 \\
\hline & $13-16$ & .82 & $1,114,439$ & 63.9 & 63.9 & 19.8 \\
\hline \multirow[t]{2}{*}{ Factor muck } & $0-4$ & .87 & $1,182,392$ & 65.6 & 29.6 & 36.0 \\
\hline & $16-20$ & .60 & 815,215 & 53.4 & 32.7 & 20.7 \\
\hline \multirow[t]{2}{*}{ Factor marly muck } & $0-4$ & .63 & 856,215 & 103.8 & 58.8 & 45.0 \\
\hline & $24-38$ & .14 & 190,270 & 560.0 & 157.1 & 402.9 \\
\hline
\end{tabular}

${ }^{3}$ Water retained between $1 / 2-$ and 10 -atmosphere tension.

varies from $0.14 \mathrm{~g} / \mathrm{cc}$ in the 24- to 38-inch layer of Factor marly muck to 0.87 in the 0 - to 4 -inch layer of Factor muck. These soils are very light by all standards of comparison. As can be expected, soil weight by volume increases as organic material decreases and mineral content increases. This is very evident in the Factor marly muck profile where the light 24- to 38-inch layer is mostly muck while the upper heavier 0- to 4-inch layer is mostly marl. The weight of the acre-furrow slice ranges from a low value of 190,000 to a high of $1,180,000$ pounds. Comparative data (5) from mineral soils usually show much higher values, even above 2-million pounds.

Moisture retention values are high at tensions in the vicinity of $1 / 2$ atmosphere. The lowest value recorded is for 16- to 20-inch layer of Factor muck and is approximatcly 53.4 percent. An extreme high of 560 percent was recorded for the 24- to 38-inch layer of Factor marly muck. This marly horizon shrinks to a very low volume when dry. Moisture levels at a 
tension approaching 10 atmospheres are extremely high. The lowest value approaches 30 percent, with a high value of 84 , and an extremely high value of 157. In general, although these soils appear to have high field capacities ( $1 / 2$ atmosphere of pressure), the moisture retained at tensions approaching permanent wilting (considered as 10 atmospheres of pressure in this case) is so high that not much water remains in the available water range.

In a well-managed program these data must be taken into consideration. Keeping the water table as high as plants will tolerate and cultivation practices permit might be helpful in assuring a source of moisture for growing plants. Keeping the water table high is also about the only effective mean of reducing microbial oxidation, settling, and fire hazards. Such a practice should prolong the effective life and agricultural value of the mucks.

\section{SUMMARY}

Data are presented in this paper from exploratory tests on some of the physical properties of the organic soils of Caño Tiburones, the largest single body of this nature in Puerto Rico. Soils are very light in weight and are capable of retaining a large percentage of moisture at $1 / 2$ and 10 atmospheres of pressure. The volume of water available for plant growth is low because of the high volumes retained when approaching higher tensions. Careful management of the water table might be the key to increased productivity and increased life-span of these valuable soils

\section{RESUMEN}

En este artículo se presentan los datos obtenidos de un estudio exploratorio sobre algunas de las propiedades físicas de los suelos orgánicos del área de Caño Tiburones, el área más grande de este tipo de suelos en Puerto Rico. Estos suelos son muy livianos y pueden retener grandes cantidades de humedad bajo condiciones en que prevalezcan presiones de $1 / 2$ y 10 atmósferas. El volumen de agua disponible para el desarrollo de las plantas es bajo debido al alto volumen que de ella retienen estos suelos al aproximarse a tensiones altas. Se sugiere que el manejo cuidadoso del nivel freático pueda ser la clave para aumentar la productividad y prolongar la utilidad de estos suelos para fines agricolas.

\section{LITERATURE CITED}

1. Alway, F. J., Agricultural value and reclamation of Minnesota peat soils, Minn. Agr. Exp. Sta. Bull. 188, 1920.

2. Bonnet, J. A., Characterization of soil units classified in the Caño Tiburones area based on laboratory data and the salinity problem, a report to the Land Authority of Puerto Rico, 1967.

3. Edelman, C. H., Soils of the Netherlands, North Holland Publishing Co., Amsterdam, 177 pp. 1950.

4. Harmer, P. R., The muck soils of Michigan, their management and uses, Mich. Agr. Exp. Sta. Bull. 314, 1941. 
5. Lugo-Lbpez, M. A., Moisture relationships of Puerto Rican soils, Agr. Exp. Sta. Univ. P. R. Tech. Paper 9, 1953.

6. - and Bonnet, J. A., Utilization of organic soils in Puerto Rico. J. Agr. Univ. P.R. 35(2): 57-65, 1951.

7. Roberts, R. C., Soil survey of Caño Tiburones area, Puerto Rico, a report to the Land Authority of Puerto Rico. 1967. 